\title{
Vinyl chloride monomer production catalysed by gold: A review
}

\author{
Catherine J. Davies, Peter J. Miedziak, Gemma L. Brett, Graham J. Hutchings* \\ Cardiff University, Main Building, Park Place, Cardiff, CF10 3AT, UK
}

\section{A R T I C L E I N F}

\section{Article history:}

Received 22 April 2016

Accepted 6 June 2016

Published 5 October 2016

\section{Keywords:}

Gold

Acetylene

Hydrochlorination

Vinyl chloride monomer

Poly vinyl chloride

Catalysis

\begin{abstract}
A B S T R A C T
In this review we discuss the history of research into the use of gold for the acetylene hydrochlorination reaction, and describe the recent developments which have led to its commercialisation. We discuss the use of different precursors and the addition to gold of a secondary metal as methods which attempt to improve these catalysts, and consider the nature of the active gold species. The vast majority of poly vinyl chloride (PVC) produced globally still uses a mercuric chloride as a catalyst, despite the environmental problems associated with it. Due to the agreement by the Chinese government to remove mercury usage in the PVC industry over the course of the next few years there is an obvious need to find a replacement catalyst; the potential use of gold for this process has been well known for several decades and to date gold seems to be the best candidate for this, primarily due to its superior selectivity when compared to other metals.
\end{abstract}

(C) 2016, Dalian Institute of Chemical Physics, Chinese Academy of Sciences. Published by Elsevier B.V. All rights reserved.

\section{Introduction}

Vinyl chloride monomer (VCM) is the monomer from which poly vinyl chloride (PVC) is made. PVC is one of the most commonly used plastics and has a wide range of applications, for example in packaging, construction materials, medical devices and clothing. This is largely due to the ability to modify the properties of the substance using additives, for example to alter its rigidity. As a result, there is a high demand for the plastic, with over 40 million tonnes of PVC produced every year, leading to VCM being a very valuable chemical. The vast majority of VCM (around 90\%) is used in the manufacture of PVC, with its alternative use being in the manufacture of chlorinated solvents.

There are a number of routes by which VCM may be produced industrially, depending on the starting material used. The most commonly used process in countries where oil is readily available is known as the balanced process; it is a combination of chlorination and oxychlorination reactions using ethene, which is oil-derived, as the starting material. Another, simpler method is the direct hydrochlorination of acetylene, which is a coal-derived starting material, and this reaction is traditionally catalysed by carbon-supported mercuric chloride. This latter route is how VCM was historically produced, and is now commonly used in China due to the availability of inexpensive coal, with over 13 million tonnes per year of VCM manufactured this way. However, the deactivation of the mercury-based catalysts is a significant problem and in addition to the decrease in activity, leaching of the mercury from the catalyst can be problematic due to its toxic nature. The resultant environmental issues with using mercury and the continued use of this process indicate the need for a new catalyst. In fact, the Minamata convention regarding mercury usage includes a clause which states that new VCM plants will not be allowed to use a mercury catalyst after 2017 and all VCM plants must be mercury-free after 2022. This has led to a resurgence in research in this field due to the necessity for a new, mercury-free catalyst. Gold is an excellent candidate for such a catalyst; in

* Corresponding author. E-mail: Hutch@cardiff.ac.uk

DOI: 10.1016/S1872-2067(16)62482-8 | http://www.sciencedirect.com/science/journal/18722067 | Chin. J. Catal., Vol. 37, No. 10, October 2016 
this review we discuss the history of research into its use for the acetylene hydrochlorination reaction, and describe the recent developments which have led to its commercialisation and the continuing research in this field.

\section{The beginnings of gold catalysis}

While supported metal catalysts have been used in industrial processes for a number of decades, the potential use of gold in such catalysts is a more recent development. At around a similar time, in the 1980s, two key discoveries were made which led to the now vast amounts of research being carried out into gold catalysts for a wide range of applications. Hutchings predicted and subsequently confirmed that based on electrode potentials, gold should be the most active metal for the hydrochlorination of acetylene, catalysed by carbon-supported metal chloride catalysts [1,2]. Meanwhile Haruta et al. [3] demonstrated that gold nanoparticles supported on transition metal oxides, e.g. $\mathrm{Fe}_{2} \mathrm{O}_{3}$, are active for the catalytic oxidation of $\mathrm{CO}$ at low temperatures. Previously, gold had largely been considered unreactive, although the use of gold catalysts had been reported for oxidations of ethylene and propylene [4] and reductions of olefins [5]. However, these new findings illustrated the potential use of gold as a catalyst when present in nanoparticle form. Since then, research into gold catalysis has increased virtually exponentially, leading to the publication of the first book on this subject in 2006 [6].

Despite their use even to the present day, deactivation of mercury-based catalysts has long been a problem; this was being investigated in some detail in the mid-1980s [7-9]. Prior to this, a study by Shinoda [10] investigated the activity of a wide range of carbon supported metal chloride catalysts for acetylene hydrochlorination and correlated the activity with the electron affinity of the metal cation, divided by the metal valence. The correlation consisted of two straight lines and is shown in Fig. 1; it can be seen that mercury has one of the

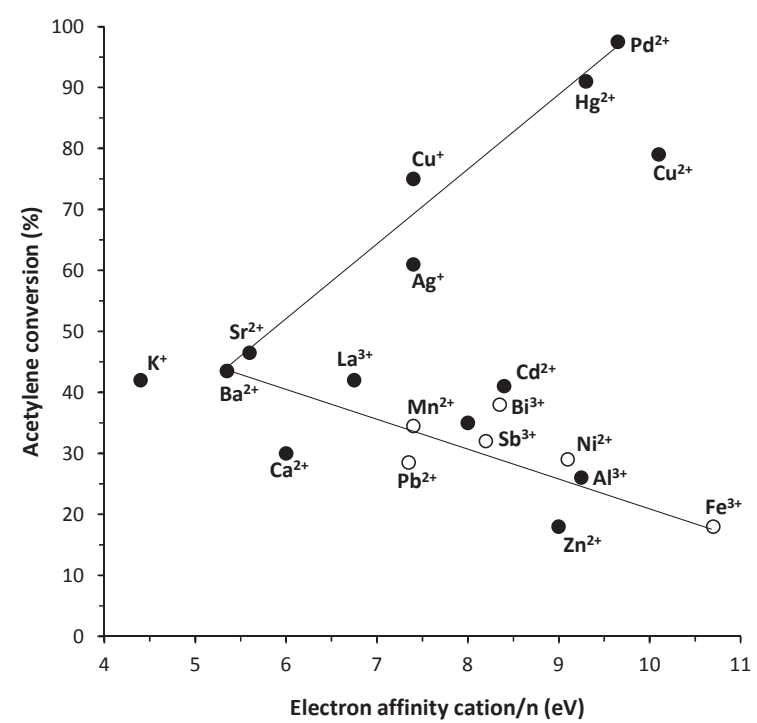

Fig. 1. Correlation of activity for acetylene hydrochlorination with electron affinity/metal valence for a range of carbon supported metal chlorides, replotted based on the data in Ref. [12].

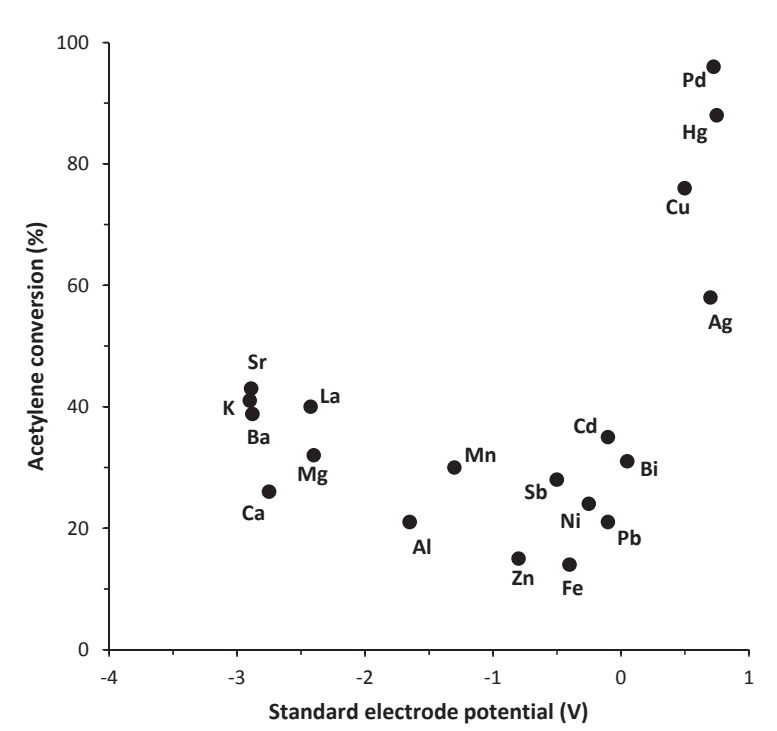

Fig. 2. Correlation of activity for acetylene hydrochlorination of carbon supported metal chloride catalysts with the standard electrode potential of the metal, $\mathrm{M}^{n+}+n \mathrm{e}^{-} \rightarrow \mathrm{M}$, replotted based on the data in Ref. [12].

highest activities of any of the metals considered. This correlation was used as a starting point for identification of potential improved catalysts for this reaction; subsequently, considering that the reaction is most likely a two-electron process, whereas electron affinity concerns a one-electron process, a study by Hutchings instead correlated the activity of supported metal chloride catalysts with their standard electrode potential [1] and obtained a curve, shown in Fig. 2. Based on this curve it was suggested that since its standard electrode potential has a greater value than those metals investigated, gold should be the most active metal for this reaction; this was later confirmed $[2,11]$ and is illustrated in Fig. 3.

This correlation was further developed by Conte et al. [13]

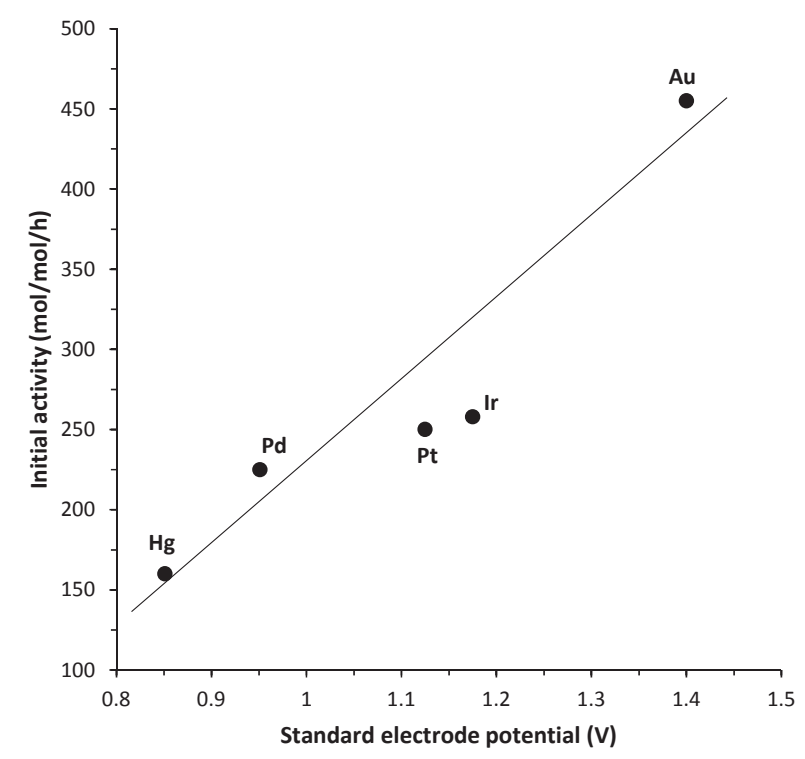

Fig. 3. Correlation of initial acetylene hydrochlorination activity with standard electrode potential for supported metal chlorides including $\mathrm{Au}$ replotted based on the data in Ref. [12]. 


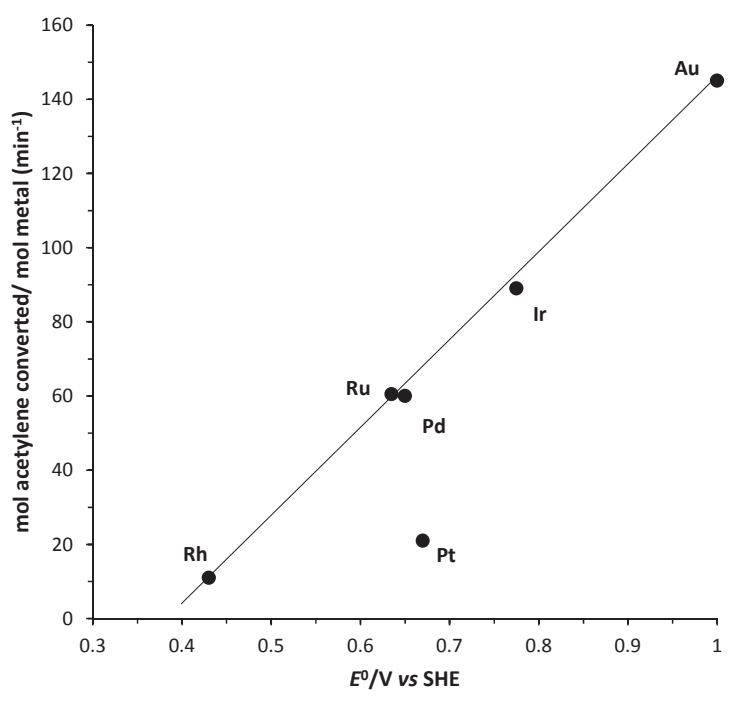

Fig. 4. Correlation of initial acetylene hydrochlorination activity of supported metal chloride catalysts with the standard electrode potential of metal chloride salts: $\left(\mathrm{RhCl}_{6}\right)^{3-},\left(\mathrm{RuCl}_{5}\right)^{2-}, \mathrm{PdCl}_{2},\left(\mathrm{PtCl}_{6}\right)^{2-},\left(\mathrm{IrCl}_{6}\right)^{3-}$ and $\left(\mathrm{AuCl}_{4}\right)^{-}$for the corresponding metals, replotted based on the data in Ref. [13]

where the standard electrode potential of the metal chloride salt was used; this is shown in Fig. 4. This further confirms the correlation of catalyst activity with standard electrode potential, although in this case the platinum is an anomalous point. This has previously been explained in terms of the extremely fast deactivation of platinum catalysts and the $4+$ oxidation state of the platinum, which is unlikely to form complexes with alkynes [12].

In addition to the highest activity being observed from gold catalysts, another advantage is that they are found to have a much higher selectivity to the desired VCM, greater than 99.5\%, whereas a secondary hydrochlorination reaction leading to the production of dichloroethane often occurs with other metals. Deactivation of these early gold catalysts is, however, still a problem and this was investigated by Nkosi et al. [11]. It was determined that whilst leaching of the metal chloride from the support was the main contributor to loss of activity for a number of metals, this was not the case for gold catalysts. The effect of reaction temperature on deactivation rate was investigated; it was observed that a minimum deactivation rate occurred at $100{ }^{\circ} \mathrm{C}$, indicating that two different deactivation mechanisms were in operation (Fig. 5). At temperatures of $60-100{ }^{\circ} \mathrm{C}$ the deactivation was found to be due to deposition of carbonaceous residues on the catalyst surface, likely caused by polymerisation reactions, whereas at $120-180{ }^{\circ} \mathrm{C}$ it is attributed to the reduction of cationic gold species ( $\mathrm{Au}(\mathrm{III})$ and $\mathrm{Au}(\mathrm{I})$ ) to $\mathrm{Au}^{0}$. Although this suggests that $100{ }^{\circ} \mathrm{C}$ may be the optimum reaction temperature, the activity at this temperature is considered to be too low and so a temperature of around $180{ }^{\circ} \mathrm{C}$ continues to be used for catalyst testing.

Since the reduction of cationic gold species is observed to be detrimental to catalyst activity [14], a number of treatments were subsequently investigated and demonstrated to be able to regenerate the activity of catalysts which deactivated during

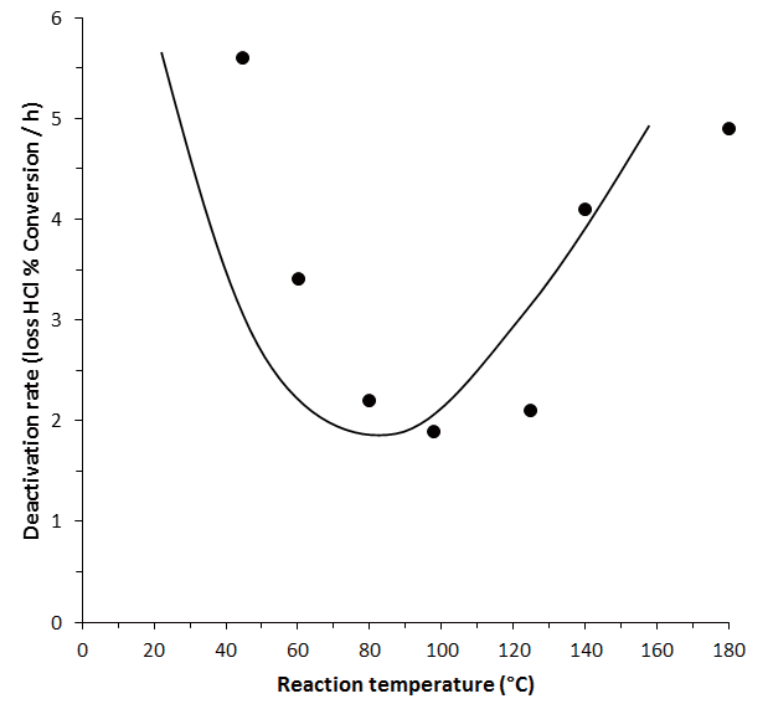

Fig. 5. The effect of reaction temperature on the deactivation rate of $\mathrm{Au} / \mathrm{C}$ catalysts for acetylene hydrochlorination, replotted based on the data in Ref. [12].

testing at the higher temperature range $\left(180{ }^{\circ} \mathrm{C}\right)$ by re-oxidation of the gold [15]. $\mathrm{Cl}_{2}$, $\mathrm{NO}$, and $\mathrm{N}_{2} \mathrm{O}$ were all found to be effective in restoring catalyst activity, while previously it had also been shown that treatment with $\mathrm{HCl}$ could be used for catalyst reactivation [16]. The re-oxidation of the gold to its cationic state in order to regenerate the catalytic activity is also supported by more recent work, where it was found by Conte et al. [17] that treatment of a deactivated catalyst outside the reactor, by boiling in aqua regia, was able to do the same. X-ray photoelectron spectroscopy (XPS) and Mossbauer spectroscopy were used to identify the presence of $\mathrm{Au}^{3+}$ on the catalyst surface and correlate this with the observed activity.

Investigations into bimetallic gold-based catalysts for this reaction were also carried out. A further study by Conte et al. [13] investigated the effect of addition of a range of precious metals to the gold and while in some cases an enhanced initial catalyst activity was observed, it was concluded that the $\mathrm{Au}$ only catalyst was still the best option, largely due to the greater selectivity to the desired product that was obtained [13]. More recently, studies have reported high activity and selectivity from bimetallic catalysts, with copper [18] and lanthanum [19] the metals added to the gold. The conditions were optimised for the $\mathrm{Au}-\mathrm{Cu} / \mathrm{C}$ catalyst and both conversion and selectivity of greater than $99.5 \%$ were obtained, however, this used an extremely low gas hourly space velocity (GHSV) of $50 \mathrm{~h}^{-1}$, compared to the GHSVs of $870 \mathrm{~h}^{-1}$ used in the studies of the monometallic gold catalysts [20]. For the Au-La/C catalyst a similarly high conversion and selectivity were obtained, also using a lower (but to a lesser extent) space velocity of $360 \mathrm{~h}^{-1}$. In this case it was determined that the addition of the lanthanum stabilised the active $\mathrm{Au}^{3+}$ species, increasing the lifetime of the catalyst.

The interest in the need for a new catalyst for acetylene hydrochlorination has also led to alternatives to gold-based catalysts being reported. These include mechanically activated $\mathrm{K}_{2} \mathrm{PdCl}_{4}, \mathrm{~K}_{2} \mathrm{PtCl}_{6}$ and $\mathrm{K}_{2} \mathrm{PtCl}_{4}$ salts [21-23], ionic liquids [24], 
Pt(II) complex solutions [25], palladium-based catalysts [26] and a liquid phase rhodium catalyst [27].

\section{Mechanism of acetylene hydrochlorination}

Kinetic studies of acetylene hydrochlorination over Au catalysts found that the reaction is first order with respect to both acetylene and $\mathrm{HCl}$ [15], and formation of a $\mathrm{C}_{2} \mathrm{H}_{2} / \mathrm{Au} / \mathrm{HCl}$ complex has been suggested. Previous work has also suggested that the reaction may proceed via a redox cycle involving the cationic gold species, although until recently little had been done to determine the mechanism of the reaction. Conte et al. [20] now have, however, carried out a detailed investigation into the mechanism of the reaction. Considering that catalyst deactivation occurs due to reduction of cationic gold species to the metallic state, the effects of the individual reactants on the catalyst were investigated since acetylene is known to be a reducing agent. A series of experiments involving sequential exposure of catalyst to the individual reactants both prior to and during reaction found that exposure to $\mathrm{HCl}$ enhanced the activity, whereas exposure to acetylene led to catalyst deactivation. This is illustrated in Fig. 6. In addition, it was found that the activity of the catalyst increases upon increasing the $\mathrm{HCl}: \mathrm{C}_{2} \mathrm{H}_{2}$ ratio in the reactant gas feed.

Due to the symmetric nature of acetylene, mechanistic data is unobtainable since each possible product (syn- and anti- addition and Markovnikov and anti-Markovnikov products) is identical. For this reason, experiments with substituted alkynes were carried out. It was found that activity was affected by steric hindrance of the substrates, with the observed trend in activity of acetylene $(40 \%)>$ hex-1-yne $(10 \%)>$ phenylacetylene $(7 \%)>$ hex-2-yne (2\%). These substrates are shown in Fig. 7. Further investigation of these reactions using deuterated

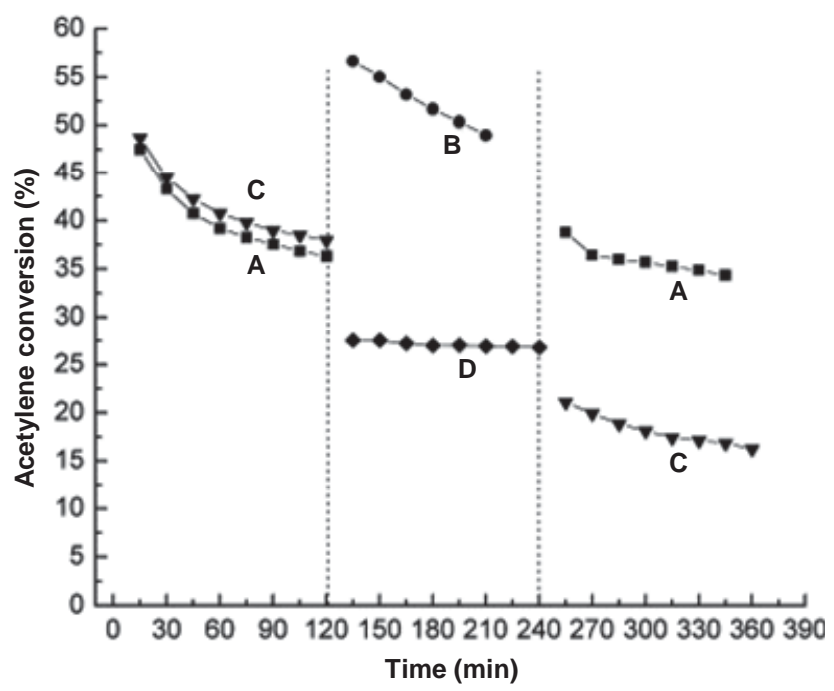

Fig. 6. Sequential flow experiments to evaluate the effect of each reactant for acetylene hydrochlorination over $\mathrm{Au} / \mathrm{C}$ catalyst. Experiment $\mathrm{A}$ : $\mathrm{C}_{2} \mathrm{H}_{2} / \mathrm{HCl}(2 \mathrm{~h}) \rightarrow \mathrm{He} / \mathrm{Cl}(2 \mathrm{~h}) \rightarrow \mathrm{C}_{2} \mathrm{H}_{2} / \mathrm{HCl}(2 \mathrm{~h}) ;$ Experiment B: $\mathrm{He} / \mathrm{HCl}$ $(2 \mathrm{~h}) \rightarrow \mathrm{C}_{2} \mathrm{H}_{2} / \mathrm{HCl}(2 \mathrm{~h}) \rightarrow \mathrm{He} / \mathrm{HCl}(2 \mathrm{~h})$; Experiment C: $\mathrm{C}_{2} \mathrm{H}_{2} / \mathrm{HCl}(2 \mathrm{~h})$ $\rightarrow \mathrm{He} / \mathrm{C}_{2} \mathrm{H}_{2}(2 \mathrm{~h}) \rightarrow \mathrm{C}_{2} \mathrm{H}_{2} / \mathrm{HCl}(2 \mathrm{~h})$; Experiment D: $\mathrm{C}_{2} \mathrm{H}_{2} / \mathrm{He}(2 \mathrm{~h}) \rightarrow$ $\mathrm{C}_{2} \mathrm{H}_{2} / \mathrm{HCl}(2 \mathrm{~h}) \rightarrow \mathrm{C}_{2} \mathrm{H}_{2} / \mathrm{He}(2 \mathrm{~h})$ reproduced with permission from Ref. [20].

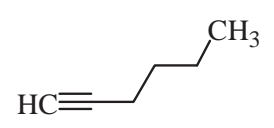

(1)

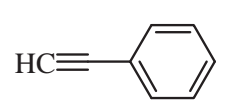

(2)
(3)

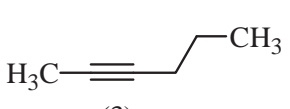

Fig. 7. Substituted alkyne substrates used to investigate the mechanism of addition of $\mathrm{HCl}$ across the alkyne bond. (1) Hex-1-yne; (2) Phenylacetylene; (3) Hex-2-yne.

substrates (DCl) led to the conclusion that the reaction proceeds via anti-addition of $\mathrm{HCl}$ across the carbon-carbon triple bond.

This result is important as it means that a typical Eley-Rideal mechanism, where only the acetylene is adsorbed on the gold surface and the $\mathrm{HCl}$ reacts with it directly from the gas phase, may be eliminated, since this would result in syn-addition. A reaction scheme in which a $\mathrm{C}_{2} \mathrm{H}_{2} / \mathrm{Au} / \mathrm{HCl}$ complex is formed has therefore been suggested, using $\left[\mathrm{AuCl}_{4}\right]^{-}$as the active site on the catalyst surface (Fig. 8).

DFT calculations were carried out using $\mathrm{C}_{2} \mathrm{H}_{2}, \mathrm{HCl}$ and $\mathrm{AuCl}_{3}$ as the active site. Detailed computational analysis of the activation of alkynes by gold(III) has been published by Hashmi and co-workers $[28,29]$. It was found that the simultaneous coordination of $\mathrm{C}_{2} \mathrm{H}_{2}$ and $\mathrm{HCl}$ to the $\mathrm{Au}^{3+}$ centre was unlikely due to the instability of a pentacoordinate gold atom and it was suggested instead that the acetylene coordinates to the gold centre first then sequential addition of the chlorine and hydrogen occurs, from a $\mathrm{HCl}$ molecule that is hydrogen-bonded to a chloride ligand of the Au centre. The reaction pathway is shown in Fig. 9.

The mechanism of acetylene hydrochlorination catalysed at room temperature by the mechanically activated platinum and palladium salts is described by Mitchenko et al. [30]. The first step is $\pi$-coordination of the carbon-carbon triple bond to the

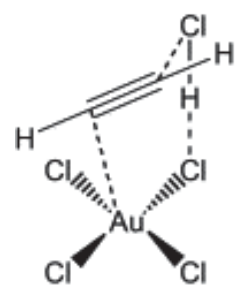

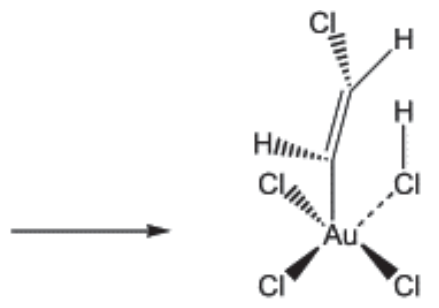<smiles>ClC=C(Cl)[Ge](Cl)(Cl)Cl</smiles><smiles></smiles>
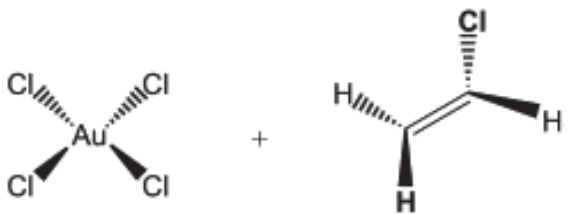

Fig. 8. Proposed model for acetylene hydrochlorination over an $\mathrm{Au} / \mathrm{C}$ catalyst involving formation of a $\mathrm{C}_{2} \mathrm{H}_{2} / \mathrm{Au} / \mathrm{HCl}$ complex, reproduced with permission from Ref. [20]. 


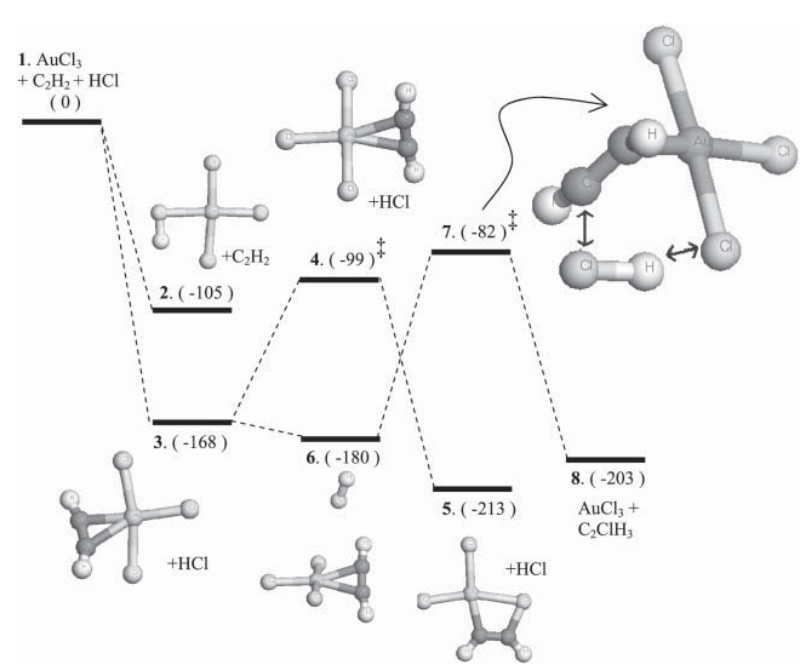

Fig. 9. Reaction energy profile for acetylene hydrochlorination over $\mathrm{Au} / \mathrm{C}$ catalyst, assuming active sites to be $\mathrm{AuCl}_{3}$ centres on catalyst surface. Energies are in $\mathrm{kJ} / \mathrm{mol}$. Transition states are denoted by + . Reproduced with permission from Ref. [20].

metal, then nucleophilic attack may occur from either the chlorine ligand of the complex or the $\mathrm{HCl}$, leading to the cis- and trans- products respectively after protodemetalation. In this case they determine the catalytic active sites to be platinum (IV) complexes with a coordination vacancy, $\left[\mathrm{PtCl}_{5} *\right.$ ], for the $\mathrm{K}_{2} \mathrm{PtCl}_{6}$ and platinum (II) acetylene $\pi$-complexes for the $\mathrm{K}_{2} \mathrm{PtCl}_{4}$ salt. In both cases the rate determining step is considered to be acetylene chloroplatination, involving a $\mathrm{HCl}$ molecule. This mechanism is similar to that proposed for the reaction over gold catalysts, in that they both involve coordination of the alkyne to the active site followed by interaction with a chloride species.

\section{Modern developments}

Since around 2012 there has been a substantial increase in the amount of research carried out into mercury-free catalysts for hydrochlorination, as rather than just being desirable, this change is now necessary over the course of the next few years. Fig. 10 shows the number of publications per year for "acetylene hydrochlorination" and "acetylene hydrochlorination and gold" based on data obtained from searches on Web of Science.

In even the most recent research into acetylene hydrochlorination catalysts, the use of supported gold is still a core idea that is being utilised. Following on from the recent work by the Hutchings group $[13,17,20,31,32]$, it seems to be generally accepted that it is necessary for the gold to be highly dispersed and in an oxidized state; while gold catalysts are frequently demonstrated to be highly active and selective for the reaction, their stability is still considered a problem. There are a number of ways in which people are attempting to remedy this, such as by adding additional metal species, using alternative supports and using alternative ligands/impregnation methods to the traditional impregnation from $\mathrm{HAuCl}_{4}$ in aqua regia, all of which will be discussed in more detail below.

There are a number of recent bimetallic catalysts that have

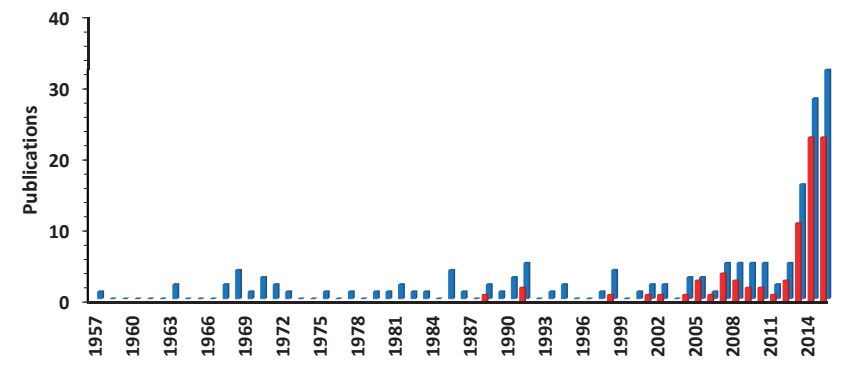

Fig. 10. Number of publications per year based on Web of Science searches for 'acetylene hydrochlorination' (blue) and 'acetylene hydrochlorination and gold' (red).

been reported in the literature, including $\mathrm{Au}-\mathrm{Sr}$ [33], $\mathrm{Au}-\mathrm{Sn}$ [34], Au-Ba [35], Au-Bi [36], Au-Cs [37] and Au-Cu [38,39]. The same group who reported the $\mathrm{Au}-\mathrm{Cs}$ catalyst have also reported trimetallic catalysts with improved activity, such as $\mathrm{Au}-\mathrm{Cs}-\mathrm{Cu}$ [40] and Au-Cs-In [38]; a highly active Au-Co-Cu catalyst has also been reported [41]. Catalysts which utilize a metal oxide in addition to the $\mathrm{Au}$ on an activated carbon support have also been investigated, for example $\mathrm{CeO}_{2}$ [42] and $\mathrm{TiO}_{2}$ [43]. In each of these cases, the enhanced activity/stability of the catalysts is considered to be a result of one or more of the following: inhibited reduction of $\mathrm{Au}^{3+}$ to $\mathrm{Au}^{0}$, high $\mathrm{Au}$ dispersion, inhibition of coke deposition on the surface and enhanced adsorption of the reactants. However, as mentioned previously, it is important to note the reaction conditions that are being used when comparing catalyst testing results - extremely high activities and selectivies are reported in many cases, however the GHSV used can be very low. Although the majority of Au catalysts for this reaction use an activated carbon support, there are a small number of cases of other supports being used, for example $\mathrm{Al}_{2} \mathrm{O}_{3}$ $[38,44]$.

The use of alternative ligands, however, is the way in which improvement to the traditional gold catalyst has been the most successful, leading to commercialisation of such a catalyst. The use of aqua regia in the catalyst preparation added a significant cost in terms of its handling/recycling/disposal. Furthermore, from a commercial point of view, lowering the gold loading whilst maintaining/improving the catalyst lifetime would give a significant advantage. Carthey et al. [45] reported that when the catalyst was prepared using aqua regia the loading of the gold could be reduced to $0.5 \mathrm{wt} \%$ without significant reduction of the activity; however, the use of aqua regia resulted in strong acid sites on the carbon that catalysed polymerisation reactions, which led to the formation of carbon nanofibers that caused catalyst deactivation. The significant development step for the catalyst was to change the gold precursor from one with hard donor ligands (Cl) to one with soft donor ligands, in particular thiosulphate (Table 1). Full details of all the ligands studied are reported in the patent [45] and discussion of the commercialisation is covered in detail in a perspective by Johnston et al. [46] The authors conclude that complexes with a high stability constant form highly active catalysts because the stability of the gold sulphur bond facilitates the creation of a stable cationic gold species that is highly dispersed. Using these 
Table 1

Catalyst screening of $\mathrm{Au} / \mathrm{C}$ catalysts prepared using different precursor complexes, redrawn from data in Ref. [46].

\begin{tabular}{|c|c|c|}
\hline Au precursor complex & $\mathrm{Au}(\%)$ & Conversion $(\%)$ \\
\hline $\mathrm{Au}\left(\mathrm{CS}\left(\mathrm{NH}_{2}\right)_{2}\right.$ & 0.1 & 95 \\
\hline $\mathrm{Na}_{3} \mathrm{Au}\left(\mathrm{S}_{2} \mathrm{O}_{3}\right)_{2}$ & 0.1 & 86 \\
\hline $\mathrm{KAu}(\mathrm{CN})_{2}$ & 0.1 & 85 \\
\hline$\left(\mathrm{NH}_{4}\right)_{3} \mathrm{Au}\left(\mathrm{S}_{2} \mathrm{O}_{3}\right)_{2}$ & 0.1 & 75 \\
\hline $\mathrm{KAu}(\mathrm{SCN})_{4}$ & 0.1 & 74 \\
\hline $\mathrm{Ca}_{3}\left[\mathrm{Au}\left(\mathrm{S}_{2} \mathrm{O}_{3}\right)_{2}\right]_{2}$ & 0.1 & 74 \\
\hline $\mathrm{KAu}(\mathrm{CN})_{4}$ & 0.1 & 69 \\
\hline $\mathrm{Au}(\mathrm{NCNH} 2)_{2}$ & 0.1 & 55 \\
\hline $\mathrm{HAuCl}_{4}+$ Aqua regia & 1.0 & 52 \\
\hline $\mathrm{HAu}\left(\mathrm{C}_{3} \mathrm{Cl}_{3} \mathrm{~N}_{3} \mathrm{O}_{3}\right)_{3} \mathrm{Cl}$ & 1.0 & 52 \\
\hline$\left[\mathrm{Au}\left(\mathrm{P}\left(\mathrm{NCH}_{2} \mathrm{CH}_{2} \mathrm{OCH}_{2} \mathrm{CH}_{2}\right)_{3}\right)_{2}\right] \mathrm{NO}_{3}$ & 1.0 & 33 \\
\hline$\left[(\mathrm{AuCl})_{2} \mathrm{dppe}\right]$ & 1.0 & 14 \\
\hline$\left[\mathrm{Au}(\mathrm{en})_{2}\right] \mathrm{Cl}_{3}$ & 1.0 & 14 \\
\hline $\mathrm{HAuCl}_{4}+\mathrm{H}_{2} \mathrm{O}$ & 1.0 & 11 \\
\hline Blank carbon extrudate (no Au) & 0 & 7 \\
\hline
\end{tabular}

Test conditions: catalyst $5 \mathrm{~g}, \mathrm{HCl}$ flow $60 \mathrm{~mL} / \mathrm{min}, \mathrm{C}_{2} \mathrm{H}_{2}$ flow 50 $\mathrm{mL} / \mathrm{min}$. Reactor set point temperature $=130{ }^{\circ} \mathrm{C}$. Total GHSV $=500 \mathrm{~h}^{-1}$. Conversion measured after $24 \mathrm{~h}$ reaction time.

alternative gold ligands, active catalysts with loadings as low as $0.15 \mathrm{wt} \%$ Au were found to be active.

These catalysts were tested by Johnson Matthey in conjunction with a Chinese PVC producer in a pilot plant. The new catalysts, prepared by supporting $\mathrm{Na}_{3} \mathrm{Au}\left(\mathrm{S}_{2} \mathrm{O}_{3}\right)_{2}$ on carbon extrudates, were significantly more stable than the mercuric chloride catalyst and subsequently a full scale reactor trial was commissioned with $1.6 \mathrm{t}$ of catalyst for more than $4500 \mathrm{~h}$ time online; the catalyst was found to have excellent stability, generally maintaining $>90 \%$ acetylene conversion.

The approach of using potassium thiocyanate as a precursor has also been reported by Zhou et al. [47]; they prepared gold and gold-copper bimetallic catalysts in an attempt to reduce the deactivation of the catalyst. The authors compared the thiocyanate prepared catalysts to tetrachloroaurate prepared catalysts and found that the deactivation rate was lower when the thiocyanate ligand was used. Incorporating copper into the catalysts did allow a reduction in the total gold content whilst improving the initial activity of the catalysts; however, the gold monometallic catalyst displayed the lowest rate of deactivation (Table 2).

The optimised gold from thiocyanate with copper catalyst was tested on the pilot plant scale; the catalysts showed good activity and stability over a period of $3000 \mathrm{~h}$ and post reaction analysis by XPS showed the $\mathrm{Au}^{3+}$ content increased with the length of the bed, suggesting that the loss of $\mathrm{Au}^{3+}$, rather than coking, is responsible for deactivation in this catalyst. It is also worth noting that the use of gold with a thiol precursor was subsequently reported by Hong et al. [48] again using $\mathrm{Cu}$ as a secondary metal.

While it is generally agreed that Au reduction is a key factor in catalyst deactivation, the active site for these catalysts is still not fully understood. Recent work by Chao et al. [49] supports the idea that the $\mathrm{Au}^{3+}$ species are important and provides evidence that $\mathrm{Au}^{3+}$ located at the $\mathrm{AuCl}_{3} / \mathrm{C}$ interface is the active
Table 2

Characterisation of the composition and reactivity performance in all catalysts $\left(T=180^{\circ} \mathrm{C}\right)$, redrawn from data in Ref. [47].

\begin{tabular}{|c|c|c|c|c|}
\hline $\begin{array}{l}\text { Catalyst } \\
\text { name }\end{array}$ & $\begin{array}{c}\text { Chemical } \\
\text { composition }\end{array}$ & $\begin{array}{c}\text { Deactivation rate } \\
(\% / \mathrm{min})\end{array}$ & $\begin{array}{c}\text { Selectivity } \\
(\%)\end{array}$ & $\begin{array}{l}\text { GHSV } \\
\left(\mathrm{h}^{-1}\right) \\
\end{array}$ \\
\hline Catal. A & $0.50 \mathrm{wt} \% \mathrm{Au}$ & 0.047 & $>99$ & 1200 \\
\hline \multirow[t]{2}{*}{ Catal. AS } & $0.50 \mathrm{wt} \% \mathrm{Au}$ & - & $>99$ & 1200 \\
\hline & 0.50 wt $\%$ KSCN & & & \\
\hline \multirow[t]{3}{*}{ Catal. ACS a } & 0.25 wt $\% \mathrm{Au}$ & 0.014 & $>99$ & 1200 \\
\hline & $1.62 \mathrm{wt} \% \mathrm{Cu}$ & & & \\
\hline & 2.46 wt $\% \mathrm{KSCN}$ & 0.008 & & 360 \\
\hline \multirow[t]{3}{*}{ Catal. ACK } & $0.25 \mathrm{wt} \% \mathrm{Au}$ & 0.015 & $>99$ & 360 \\
\hline & $1.62 \mathrm{wt} \% \mathrm{Cu}$ & & & \\
\hline & $1.89 \mathrm{wt} \% \mathrm{KCl}$ & & & \\
\hline \multirow[t]{2}{*}{ Catal. AC } & 0.25 wt $\% \mathrm{Au}$ & 0.017 & $>99$ & 360 \\
\hline & $1.62 \mathrm{wt} \% \mathrm{Cu}$ & & & \\
\hline
\end{tabular}

aWe only present the composition of the optimised Catal. ACS here due to too many compositions in optomisation. Deactivation rate is defined as the value of the loss of conversion per minute during the deactivation stage, which is given by $r=-\Delta$ conversion $(\%) / \Delta t(\mathrm{~min})$.

site. However, there are cases in which $\mathrm{Au}^{0}$ is reported to be key to the activity of catalysts; in two publications from one group it is reported that for both a $\mathrm{Au}-\mathrm{Cu} / \mathrm{C}$ catalyst with added thiol and $\mathrm{a} \mathrm{Au} / \mathrm{C}$ catalyst made by a novel impregnation method using alternative solvents, there was a correlation between higher activity and the presence of $\mathrm{Au}^{0}$ species $[48,50]$. However, this conclusion was drawn based on XPS data and it is known that reduction of Au species can occur due to the X-ray beam. Some of the most recent work from the Hutchings group investigated the active site by ex-situ analysis at different times during the observed induction period of the $\mathrm{Au} / \mathrm{C}$ catalyst, and proposed that it is not just $\mathrm{Au}^{3+}$ but the $\mathrm{Au}^{3+}-\mathrm{Au}^{+}$redox couple that is important for the reaction [51]. This supports previous work by Zhou et al. [36] who also observed the importance of $\mathrm{Au}^{+}$species.

\section{Conclusions}

The vast majority of PVC produced globally still uses mercuric chloride as a catalyst, despite the environmental problems associated with it. However, due to the agreement by the Chinese government to remove mercury usage in the PVC industry over the course of the next few years there is an obvious need to find a replacement catalyst; the potential use of gold for this process has been well known for several decades and to date gold seems to be the best candidate for this, primarily due to its superior selectivity when compared to other metals.

In recent years, the use of different precursors has led to improvements in the activity and stability of gold catalysts and this has allowed commercial trials to be undertaken. These trials have been successful but there is still a drive towards catalysts with even better stability, and lowering of gold content in order to reduce cost. Approaches towards this involve using different supports and the alloying of gold with a secondary metal, particularly copper. These studies show promise but gold is still the most effective catalyst. There is still debate in the literature about the nature of the active gold species in 
these catalysts, with the majority of work reporting $\mathrm{Au}^{3+}$ as the active species but some still advocating $\mathrm{Au}^{0}$. It seems clear that better understanding of the active species, by in-situ characterisation, could lead to improvements in catalyst design and more stable catalysts. Of course one of the major challenges facing scientists seeking to commercialise gold catalysts is the tendency of gold catalysts to sinter on use. For the gold catalyst for acetylene hydrochlorination the presence of $\mathrm{HCl}$ in slight excess is essential to arrest this sintering and maintain the gold in the cationic state required for this reaction. Previously, it has been shown that iodo-compounds can successfully re-disperse gold nanoparticles [52,53] and so there is immense scope to explore this effect for future applications of gold catalysts. Despite the recent commercialisation of gold catalysts for acetylene hydrochlorination that is by no means the end of the story and it seems clear that this is a field of chemistry where there are and will continue to be considerable opportunities for catalyst development and understanding.

\section{References}

[1] G. J. Hutchings, J. Catal., 1985, 96, 292-295.

[2] B. Nkosi, N. J. Coville, G. J. Hutchings, Appl. Catal., 1988, 43, 33-39.

[3] M. Haruta, T. Kobayashi, H. Sano, N. Yamada, Chem. Lett., 1987, 405-408.

[4] N. W. Cant, W. K. Hall, J. Phys. Chem., 1971, 75, 2914-2921.

[5] G. C. Bond, P. A. Sermon, G. Webb, D. A. Buchanan, P. B. Wells, J. Chem. Soc., Chem. Commun., 1973, 444-445.

[6] G. C. Bond, C. Louis, D. T. Thompson, in: G. J. Hutchings Ed., Catalysis by Gold, Imperial College Press, 2006.

[7] J. B. Agnew, H. S. Shankar, Ind. Eng. Chem. Prod. Res. Dev., 1986, 25, 19-22.

[8] H. Bremer, H. Lieske, Appl. Catal., 1985, 18, 191-203.

[9] G. J. Hutchings, D. T. Grady, Appl. Catal., 1985, 17, 155-160.

[10] K. Shinoda, Chem. Lett., 1975, 219-220.

[11] B. Nkosi, N. J. Coville, G. J. Hutchings, M. D. Adams, J. Friedl, F. E. Wagner, J. Catal., 1991, 128, 366-377.

[12] M. Conte, G.J. Hutchings, Hydrochlorination Reactions, in: A. S. K. Hashmi, F. D. Toste Eds., Modern Gold Catalyzed Synthesis, Wiley VCH Verlag GmbH, 2012.

[13] M. Conte, A. F. Carley, G. Attard, A. A. Herzing, C. J. Kiely, G. J. Hutchings, J. Catal., 2008, 257, 190-198.

[14] A. S. K. Hashmi, M. C. Blanco, D. Fisher, J. W. Bats, Eur. J. Org. Chem., 2006, 1387-1389.

[15] B. Nkosi, M. D. Adams, N. J. Coville, G. J. Hutchings, J. Catal., 1991,
$128,378-386$.

[16] B. Nkosi, N. J. Coville, G. J. Hutchings, J. Chem. Soc., Chem. Commun., 1988, 71-72.

[17] M. Conte, A. F. Carley, G. J. Hutchings, Catal. Lett., 2008, 124, 165-167.

[18] S. J. Wang, B. X. Shen, Q. L. Song, Catal. Lett, 2010, 134, 102-109.

[19] H. Y. Zhang, B. Dai, X. G. Wang, L. L. Xu, M. Y. Zhu, J. Ind. Eng. Chem., 2012, 18, 49-54.

[20] M. Conte, A. F. Carley, C. Heirene, D. J. Willock, P. Johnston, A. A. Herzing, C. J. Kiely, G. J. Hutchings, J. Catal., 2007, 250, 231-239.

[21] S. A. Mitchenko, E. V. Khomutov, A. A. Shubin, Y. M. Shul'ga, J. Mol. Catal. A, 2004, 212, 345-352.

[22] S. A. Mitchenko, T. V. Krasnyakova, R. S. Mitchenko, A. N. Korduban, J. Mol. Catal. A, 2007, 275, 101-108.

[23] S. A. Mitchenko, T. V. Krasnyakova, I. V. Zhikharev, Theor. Exp. Chem., 2008, 44, 316-319.

[24] G. Qin, Y. H. Song, R. Jin, J. Shi, Z. Y. Yu, S. K. Cao, Green Chem., 2011, 13, 1495-1498.

[25] L. A. Sil'chenko, S. A. Panova, G. K. Shestakov, O. N. Temkin, Kinet. Catal., 1997, 38, 790-794.

[26] Q. L. Song, S. J. Wang, B. X. Shen, J. G. Zhao, Pet. Sci. Technol,, 2010, 28, 1825-1833.

[27] S. A. Panova, G. K. Shestakov, O. N. Temkin, J. Chem. Soc., Chem. Commun., 1994, 977-977.

[28] M. Pernpointer, A. S. K. Hashmi, J. Theory Comput., 2009, 5, 2717-2725.

[29] M. Lean, M. Rudolph, A. S. K. Hashmi, P. Schwerdtfeger, Organometallics, 2010, 29, 2206-2210.

[30] S. A. Mitchenko, T. V. Krasnyakova, I. V. Zhikharev, Kinet. Catal., 2009, 50, 734-740.

[31] M. Conte, C. J. Davies, D. J. Morgan, A. F. Carley, P. Johnston, G. J. Hutchings, Catal. Lett., 2014, 144, 1-8.

[32] M. Conte, C. J. Davies, D. J. Morgan, T. E. Davies, A. F. Carley, P. Johnston, G. J. Hutchings, Catal. Sci. Technol, 2013, 3, 128-134.

[33] G. B. Li, W. Li, J. L. Zhang, Catal. Sci. Technol., 2016, 1821-1828.

[34] Y. Z. Dong, H. Y. Zhang, W. Li, M. X. Sun, C. L. Guo, J. L. Zhang, J. Ind. Eng. Chem., 2016, 35, 177-184.

[35] H. Y. Zhang, W. Li, X. Q. Li, W. Zhao, J. J. Gu, X. Y. Qi, Y. Z. Dong, B. Dai, J. L. Zhang, Catal. Sci. Technol., 2015, 5, 1870-1877.

[36] K. Zhou, W. Wang, Z. Zhao, G. H. Luo, J. T. Miller, M. S. Wong, F. Wei, ACS Catal., 2014, 4, 3112-3116.

[37] J. G. Zhao, J. J. Zeng, X. G. Cheng, L. Wang, H. H. Yang, B. X. Shen, RSC Adv., 2015, 5, 16727-16734.

[38] J. Zhao, J. T. Xu, J. H. Xu, J. Ni, T. T. Zhang, X. L. Xu, X. N. Li, ChemPlusChem, 2015, 80, 196-201.

[39] J. M. Ma, S. J. Wang, B. X. Shen, React. Kinet. Mech. Cat., 2013, 110, 177-186.

\section{Graphical Abstract}

Chin. J. Catal., 2016, 37: 1600-1607 doi: 10.1016/S1872-2067(16)62482-8

\footnotetext{
Vinyl chloride monomer production catalysed by gold: A review

Catherine J. Davies, Peter J. Miedziak, Gemma L. Brett,

Graham J. Hutchings*

Cardiff University, UK

This review presents the research progress of heterogeneous catalysis using gold for the acetylene hydrochorination of acetylene, with the aim of replacing toxic mercury in the commercial production of vinyl chloride monomer.
}

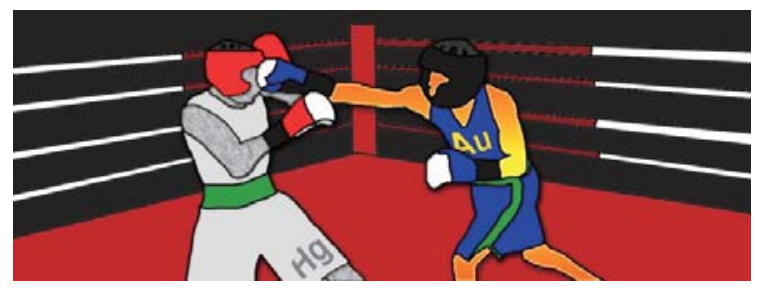


[40] J. Zhao, S. C. Gu, X. L. Xu, T. T. Zhang, X. X. Di, Z. Y. Pan, X. N. Li, RSC Adv., 2015, 5, 101427-101436.

[41] H. Y. Zhang, B. Dai, W. Li, X. G. Wang, J. L. Zhang, M. Y. Zhu, J. J. Gu, J. Catal., 2014, 316, 141-148.

[42] G. B. Li, W. Li, J. L. Zhang, Catal. Sci. Technol., 2016, 6, 1821-1828.

[43] C. F. Huang, M. Y. Zhu, L. H. Kang, X. Y. Li, B. Dai, Chem. Eng. J., 2014, 242, 69-75.

[44] J. G. Zhao, X. G. Cheng, L. Wang, R. F. Ren, J. J. Zeng, H. H. Yang, B. X. Shen, Catal. Lett., 2014, 144, 2191-2197.

[45] P. T. Bishop, N. A. Carthey, WO Patent 2013008004A2, 2013.

[46] P. Johnston, N. Carthey, G. J. Hutchings, J. Am. Chem. Soc., 2015, 137, 14548-14557.

[47] K. Zhou, J. C. Jia, C. H. Li, H. Xu, J. Zhou, G. H. Luo, F. Wei, Green
Chem., 2015, 17, 356-364.

[48] G. T. Hong, X. H. Tian, B. B. Jiang, Z. W. Liao, J. D. Wang, Y. R. Yang, J. Zheng, RSC Adv., 2016, 6, 3806-3814.

[49] S. L. Chao, Q. X. Guan, W. Li, J. Catal., 2015, 330, 273-279.

[50] X. H. Tian, G. T. Hong, B. B. Jiang, F. P. Lu, Z. W. Liao, J. D. Wang, Y. R. Yang, RSC Adv., 2015, 5, 46366-46371.

[51] X. Liu, M. Conte, D. Elias, L. Lu, D. J. Morgan, S. J. Freakley, P. Johnston, C. J. Kiely, G. J. Hutchings, Catal. Sci. Technol., 2016, DOI: 10.1039/C6CY00090H.

[52] J. Sá, S. F. R. Taylor, H. Daly, A. Goguet, R. Tiruvalam, Q. He, C. J. Kiely, G. J. Hutchings, C. Hardacre, ACS Catal., 2012, 2, 552-560.

[53] X. P. Duan, X. L. Tian, J. H. Ke, Y. Yin, J. W. Zheng, J. Chen, Z. M. Cao, Z. X. Xie, Y. Z. Yuan, Chem. Sci., 2016, 7, 3181-3187.

\section{金催化制备氯乙烯单体进展}

\section{Catherine J. Davies, Peter J. Miedziak, Gemma L. Brett, Graham J. Hutchings* \\ 卡迪夫大学, 威尔士卡迪夫, 英国}

摘要: 本文综述了 $\mathrm{Au}$ 用于乙炔氢氯化反应的研究历史、最新研究进展及商业化进程. 讨论了使用不同前驱体和添加第二 金属助剂等方法对催化剂性能的改进, 探讨了活性金物种的性质. 尽管 $\mathrm{HgCl}_{2}$ 会导致环境污染等问题, 但全球大量聚氯乙 烯(PVC)的生产仍采用 $\mathrm{HgCl}_{2}$ 作为催化剂. 由于中国计划未来几年内将不再使用 $\mathrm{Hg}$ 生产 $\mathrm{PVC}$, 因此急需探索替代催化剂. 数十年来人们普遍认为 $\mathrm{Au}$ 是该过程的最佳替代催化剂, 这主要是因为与其他金属相比, 金催化剂的选择性更高.

关键词: 金; 乙炔; 氢氯化; 氯乙烯单体; 聚氯乙烯; 催化

收稿日期: 2016-04-22. 接受日期: 2016-06-06. 出版日期: 2016-10-05.

*通讯联系人. 电子信箱: Hutch@cardiff.ac.uk

本文的英文电子版由Elsevier出版社在ScienceDirect上出版(http://www.sciencedirect.com/science/journal/18722067). 